\title{
IMPACT OF COVID-19 ON THE LIFE INSURANCE DEVELOPMENT IN SERBIA
}

\author{
Milena Nikolićn ${ }^{*}$, \\ Vladimir Mitić1,2, \\ Kristina Kaličanin ${ }^{1,2}$ \\ ${ }^{1}$ Singidunum University, \\ Belgrade, Serbia \\ ${ }^{2} \mathrm{PhD}$ candidate, \\ Singidunum University, \\ Belgrade, Serbia
}

\begin{abstract}
:
The COVID-19 pandemic has significantly influenced changes in the living conditions and business environment, both internationally and nationally. This global risk has affected many individuals, organizations, and economic sectors, causing recession, fear of losing one's life and the lives of close ones, losing jobs, business bankruptcy. Due to the pandemic, people's behaviour and life priorities have changed, influencing the development of awareness of the needs for life insurance. Furthermore, changes have affected the functioning of insurance companies, their needs to adapt to the changed environment, and finding ways to remain sustainable. The subject of this paper is an empirical analysis of the COVID-19 impacts on the life insurance development in Serbia. The aim of this paper is to point out the current trends in the domestic market of life insurance, and possible development directions for this type of insurance in an unpredictable and turbulent environment, based on the analysis of research results before and during the pandemic.
\end{abstract}

Keywords:

COVID-19, life insurance, insurance premium, insurance companies, Serbia.
Correspondence:

Milena Nikolić

e-mail:

milena.nikolic@singidunum.ac.rs

\section{INTRODUCTION}

COVID-19 was first identified in China at the end of 2019, and it rapidly spread to the rest of the world, reaching the scale of a pandemic. The introduction of the state of emergency, the physical isolation of people, the endangerment of lives and the health of people, as well as the difficult functioning of the economy have negatively affected not only individuals, but also the economy and society as a whole. People were forced to significantly change their everyday behaviour -"better handwashing, staying home more, and wearing facemasks or social distancing when outside the home" (Harris et al., 2020, p. 2). People had to pay more attention to protecting their health (Čolović \& Mitić, 2021, p. 89), and the health of their loved ones when making various decisions. Demand decreased due to limited movement during the pandemic, which affected the production of certain products and led to the shutdown or closing of small-scale enterprises. The pandemic also affected the reduced supply to a certain extent, due to the difficult supply of raw materials and workforce (World Bank Group, 2020, pp. 1-4). Moreover, an increasing number of processes we encounter daily have been digitized (Kaličanin et al., 2021, p. 111) and performed from home, and new safety and occupational safety measures have been introduced. The fear for health and life, job insecurity, social distancing, and changes in people's behaviour in their private lives and at work have negatively affected the whole society. It has become apparent that the negative economic, social and health consequences of the pandemic are far-reaching and still unpredictable. 
The COVID-19 pandemic outbreak has shown that safety and protection from numerous risks are necessary for both individuals and the economy. Life insurance is a "long-term insurance providing a significant social security, protecting individuals and families from various life adversities" (Žarković, 2008, p. 24), and is especially important under these circumstances. It helps individuals save throughout their working lives, and provide themselves with material protection against the risk of loss or decreased capacity for work, i.e., material protection for their family members (or other persons designated as beneficiaries) in the event of premature death. The development of people's awareness of the need to protect themselves and their families from the risk of loss or reduction of the ability to work and death is particularly important during the pandemic when their health and their lives are threatened. By purchasing a life insurance policy, individuals are ensuring their safety and the safety of their family. In addition, the development of the life insurance market is encouraged, and long-term savings are made, which stimulates economic growth and development.

Actualization of life insurance, as the best way of protecting people's lives, those of their families, and the standard of living in their old age are of great importance in countries where people's awareness of the need to secure against these risks is extremely low. This is exactly the case in Serbia, where people's awareness of the need to secure against all risks, especially against the risk of death, is insufficiently developed. With this in mind, the existing trends in the market of life insurance in Serbia in the period before the pandemic (regular conditions) and the period of COVID-19 pandemic are analyzed in this paper. The aim of this analysis is to determine the effect of the pandemic on the amount of a life insurance premium in the Republic of Serbia in order to stimulate the demand for insurance by educating and informing people, in order to develop a culture of saving and awareness of the need to protect against risk. That would contribute to further development of the insurance market in Serbia, and it would enable the acceleration of its financial market and economic development.

The paper covers several sections. After the introduction, the first section provides a brief literature review and recent research about the characteristics and significance of life insurance, as well as its significance in the conditions of the current COVID-19 pandemic. Methodology of empirical research of the life insurance market in Serbia is presented in the following section. Given that the trend of life insurance premium in the Republic of Serbia was analyzed in different periods (in the period before and after the crisis), the comparative method was used for comparative analysis. Descriptive statistics were applied for grouping, systematizing, calculating, for tabular and graphic presentation of the obtained data and results.
The next section presents and analyzes research results along with determining the fulfilment of the initial hypotheses. The final section of the paper summarizes conclusions of the performed analysis and empirical research, and the possibility of developing this type of insurance in the future is pointed out.

\section{LITERATURE REVIEW}

The beginnings of life insurance as a branch of insurance can be witnessed as early as the end of the 16th century in England. In Serbia, life insurance affairs started to develop at the end of the 19th century, when they were performed through branch offices of foreign insurance companies from England, Austro-Hungary, France, Italy, and other countries (Šulejić et al., 2009, pp. 13-14). After the end of the Second World War, all pre-war insurance companies were abolished, and their property was nationalized (Šulejić et al., 2009, p. 15). Further development of this type of insurance was influenced by the development of the social insurance system, i.e., the pension system and the promotion of a "state of welfare". It is a system in which, through the pension and disability insurance fund, "funds are collected from payment of contributions of the insured for a longer time period, in order to ensure their existence after the end of their working lives (through old-age or disability pension), i.e., the existence of their families in case of death of the insured (through survivor pension)" (Nikolić, 2018, p. 8). A pension system designed in this way functions as intergeneration solidarity, where the payment of pensions to pensioners, i.e., to members of their family, is made up from the contributions of employees who are employed at the time when pensioners receive those pensions (Rakić \& Nikolić, 2012, pp. 133134). In the second half of the 20th century, during the promotion of the "state of welfare" and the liberalization of retirement conditions, Serbian residents retired early and received larger pensions, so there was no need for additional savings through life insurance. However, as pension systems based on the principle of intergeneration solidarity largely depend on demographic and economic trends, which are unfavourable in most European countries and in the Republic of Serbia (Nikolić, 2018, pp. 36-56), their long-term unsustainability at the end of the 20th century became apparent. Afterwards, numerous reforms of the pension system were initiated in many European countries, as well as in the Republic of Serbia, which caused significant reductions in the pension amount received from these pension systems, and an increase in the retirement age (Nikolić, 2018). It has become clear that the safety of the elderly is uncertain. These facts created the need for additional savings for the "third age" (retirement), in order to ensure the safety of people and an adequate standard of living after the end of the working life. 
One of the best ways to save money for the "third age" is long-term special-purpose savings, achieved by purchasing a life insurance policy.

Life insurance refers to "all insurances in which the termination or duration of lives of one or more persons (the insured persons) leads to the payment of the sum insured by the insurer" (Kočović \& Šulejić, 2006, p. 350). It is an insurance based on a "contract by which the insurer, in contrast to the premiums paid, obliges to pay to the insured person or the designated person a certain amount or annuity in case of death of the insured person, or in case of his surviving to a certain time" (Kočović \& Šlejić, 2006, p. 339). In addition to life insurance, as the basic insurance, the same contract usually includes protection against additional risks (accidents, diseases), as supplementary insurance against the consequences of an accident or supplementary health insurance (Pjanić et al., 2016, p.149).

Life insurance is the most widespread form of insurance in the world because insurance and savings are realized through it simultaneously (Olević, 2016, p. 66). This is a matter of multiple significant financial activities both for individuals (insured persons) and for the economy, and society as a whole. It is important for individuals because material protection for themselves and their loved ones is provided through this type of insurance (Olevic, 2016, p. 66). Individuals (insured persons) ensure their survival, maintenance, or improvement of their standard of living during their "third age" by supplementing their retirement income, i.e., the material security for their family members or other close people in the event of death. According to a survey conducted in April 2012 by the reinsurance company Swiss $\mathrm{Re}$, most insured persons cited the possibility of serious illness, inability to pay for long-term care, as well as the inability to maintain their standard of living after retirement, as the main reasons for purchasing a life insurance policy (Munitlak-Ivanović et al., 2014, p. 63). In addition, a life insurance policy is a security (Munitlak-Ivanović et al., 2014, p. 62), so that, when saving, individuals may use it as a guarantee for obtaining a loan by encumbrance in favour of the bank. This is especially significant for consumer loans and mortgages (Olević, 2016, p. 65). The significance of life insurance for the economy and society is reflected in the fact that it is a matter of long-term special-purpose savings. Long-term accumulation of a significant amount of financial resources available in the long run for lending and investing contributes to the development of the financial market and, thus, stimulates the economic development of the country. At the same time, when individuals save for their "third age" and provide themselves with additional income sources in old age, in addition to the state pension, the social problems that the state will encounter in the future are reduced. Having this in mind, it is clear that "being uninsured is, in the long-term, the most costly option - to an individual, to an economy, to a society" (Liedtke, 2007, p. 220).

In developed countries in the world and in Europe, the importance of life insurance is obvious. The share of premium for this type of insurance in the total insurance premium is higher that the share of non-life insurance premium in the total insurance premium, and it is more than $60 \%$ (Žarković, 2008, p. 23). At the OECD-level group of countries, the share of life insurance premiums in the total insurance premium in 2019 was $49.9 \%$ (OECD, 2021). The largest share of life insurance premiums in the total insurance premium in this group of countries was noted in Finland (100\%), Luxembourg (90\%), Sweden, Italy, Japan, Ireland, and the United Kingdom (more than 70\%) (OECD, 2021). At the end of 2019, the share of life insurance premiums in the total insurance premiums in Serbia was $21 \%$ (NBS, 2019d), which is at the level of Turkey (20.1\%) and Slovenia (20.8\%), which are ranked most unfavourably according to this indicator in OECD group of countries. The data indicates that life insurance in Serbia is in the initial phase of development, and that people's awareness of the need for and importance of life insurance, as well as the characteristics of this type of savings, is insufficiently developed. Poor information and lack of education of the population about life insurance in Serbia contributes to the fact that most of the population in Serbia does not have knowledge of this type of insurance (Munitlak-Ivanović et al., 2014, p. 63), and that they consider life insurance an unnecessary expense (Liedtke, 2007, p. 220).

\section{DATA AND METHODOLOGY}

Empirical analysis of the development of life insurance in the Republic of Serbia was performed based on annual data on the amount of life insurance premiums in the period from 2005 until 2020. Analysis of the impact of the COVID-19 pandemic on life insurance in the Republic of Serbia was performed using quarterly data on life insurance premiums in the period before the outbreak of the COVID-19 pandemic (regular conditions) and during this pandemic. Considering that the COVID-19 pandemic in the Republic of Serbia manifested itself only at the end of March 2020, the period before the pandemic outbreak in this analysis includes five quarters (four quarters in 2019 and the first quarter in 2020), whereas the period of the pandemic covers the same number of quarters (three quarters in 2019 and two quarters in 2021). Secondary data from the National Bank of Serbia, the institution responsible for insurance supervision in the Republic of Serbia, was used in this analysis. 
To determine the current trends in the domestic insurance market, and possible development directions for this type of insurance in an unpredictable and turbulent environment, as well as the pandemic, the following hypotheses are tested:

H1: The COVID-19 pandemic has influenced the increase in the demand for life insurance in the Republic of Serbia,

H2: People's awareness of the need to protect themselves from the risk of death is higher during the pandemic.

The hypotheses were tested using descriptive statistics methods and comparison methods. The Microsoft Excel and statistical package SPSS were used for the data analyses.

\section{RESULTS AND DISCUSSION}

Considering the amount of life insurance premium, as one of the most frequently used indicators for analysing life insurance development, the life insurance premium amount was continuously increasing in the period from 2005 until 2020 in the Republic of Serbia. 2017 was the only exception, when the life insurance premium was slightly decreased (Figure 1).
It was increased from RSD 2,537.45 million in 2005 to RSD 23,481.71 million in 2020. The leading insurance companies in this period were Wiener Städtische Insurance, Grawe Insurance, and Delta (later Generali Insurance). In first place for life insurance market of the Republic of Serbia in the initial period was held by Wiener Städtische Insurance, ceding to Generali Insurance in 2014. Grawe Insurance held second place until 2009, and after that dropped to third.

The number of insurance companies in the life insurance sector changed in the analysed period. The average value of this insurance premium changed in accordance with that, as well as the increase of life insurance premium. It continuously increased from RSD 362,49 million in the initial period, and in 2020 it reached RSD 2,348.17 million. Wiener Städtische Insurance and Grawe Insurance are insurance companies with a higher insurance premium annually than the average annual value of life insurance premium when followed from the beginning of the analysed period.

Figure 1. Life insurance premium in the Republic of Serbia (RSD millions)

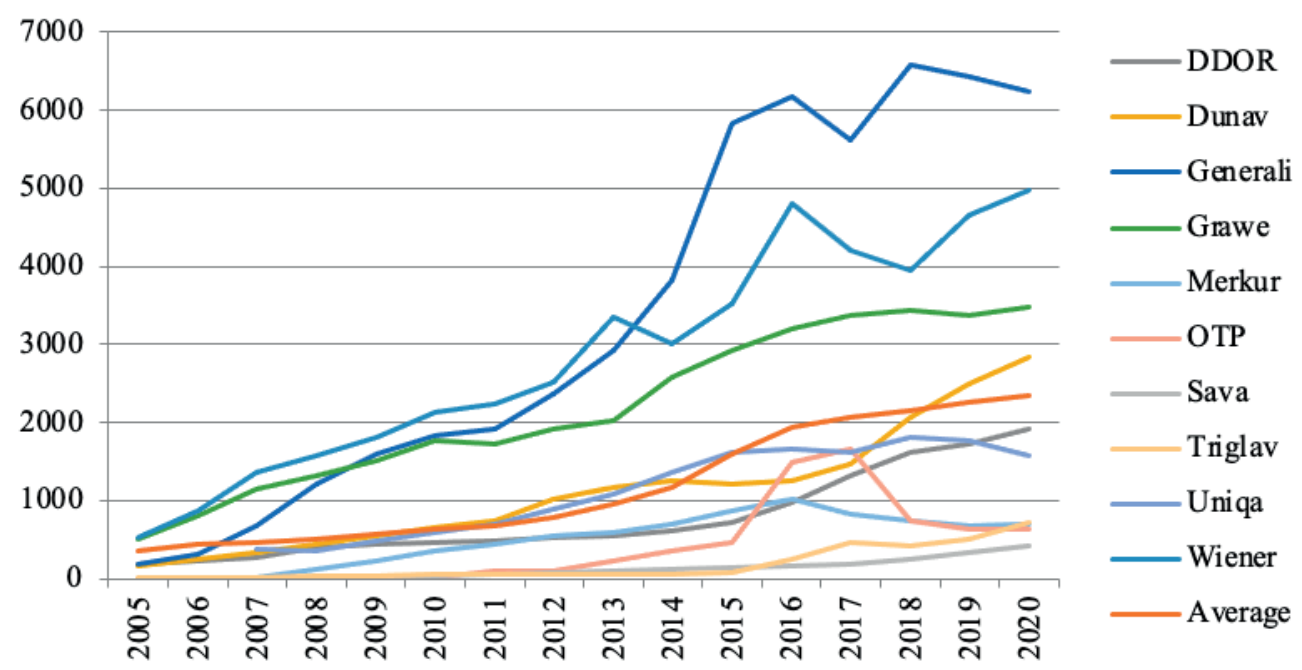

Source: Authors' presentation based on the data from NBS (2005-2020).

The trend of the life insurance premium amount was monitored in the period before the pandemic outbreak and during the pandemic with the aim of considering the impact of the COVID-19 pandemic on the increased demand for life insurance in the Republic of Serbia, (Table 1).
Total life insurance premium of all insurance companies in the period of the COVID-19 pandemic is higher for RSD 1,452.08 million in comparison to the period before the pandemic outbreak, so the noted increase of the life insurance premium was at a rate of 5.15\%. 
Table 1. Life insurance premium before (regular) and during the COVID-19 pandemic (RSD millions, \%)

\begin{tabular}{lcccc}
\hline Insurance company & Regular & COVID-19 & Difference & Change rate \\
\hline DDOR & 2167.10 & 2439.91 & 272.81 & 72.59 \\
\hline Dunav & 3096.21 & 3810.12 & 23.06 \\
\hline Generali & 8070.08 & 7971.93 & -98.15 & -1.22 \\
\hline Grawe & 4049.72 & 4453.81 & 404.09 & 9.98 \\
\hline Merkur & 810.36 & 885.13 & 74.77 & 9.23 \\
\hline OTP & 790.75 & 778.71 & -12.05 & -1.52 \\
\hline Sava & 427.68 & 568.39 & 140.70 & 32.90 \\
\hline Triglav & 669.49 & 935.00 & 265.51 & 39.66 \\
\hline Uniqa & 2149.77 & 1961.44 & -188.33 & -8.76 \\
\hline Wiener & 5969.46 & 5848.27 & -121.19 & -2.03 \\
\hline Total & 28200.63 & 29652.71 & 1452.08 & 5.15 \\
\hline Average & 2820.06 & 2965.27 & - & - \\
\hline Maximum & 1715.39 & 1863.50 & - & -
\end{tabular}

Source: Authors' calculation based on the data from NBS (2019-2021)

By observing individual insurance companies, the increase in the life insurance premium in the period of the COVID-19 pandemic is present in most - DDOR Novi Sad, Dunav Insurance, Grawe Insurance, Merkur Insurance, Sava Life Insurance and Triglav Insurance (Figure 2). The greatest increase is seen in Triglav Insurance (39.66\%) and Sava Life Insurance (32.90\%). However, despite a significant increase of the premium, these insurance companies according to the premium amount are still significantly lagging behind other insurance companies.
The reduction of life insurance premium is present in Uniqa Life Insurance (-8.76\%), Wiener Städtische Insurance (-2.03), OTP Insurance $(-1.52 \%)$ and Generali Insurance $(-1.22 \%)$. The maximum value of life insurance premium in the period before the COVID-19 pandemic and during this pandemic is noted in Generali Insurance, and the minimum value in Sava Life Insurance.

Figure 2. Life insurance premium in insurance companies before (regular) and during COVID-19 (RSD millions)

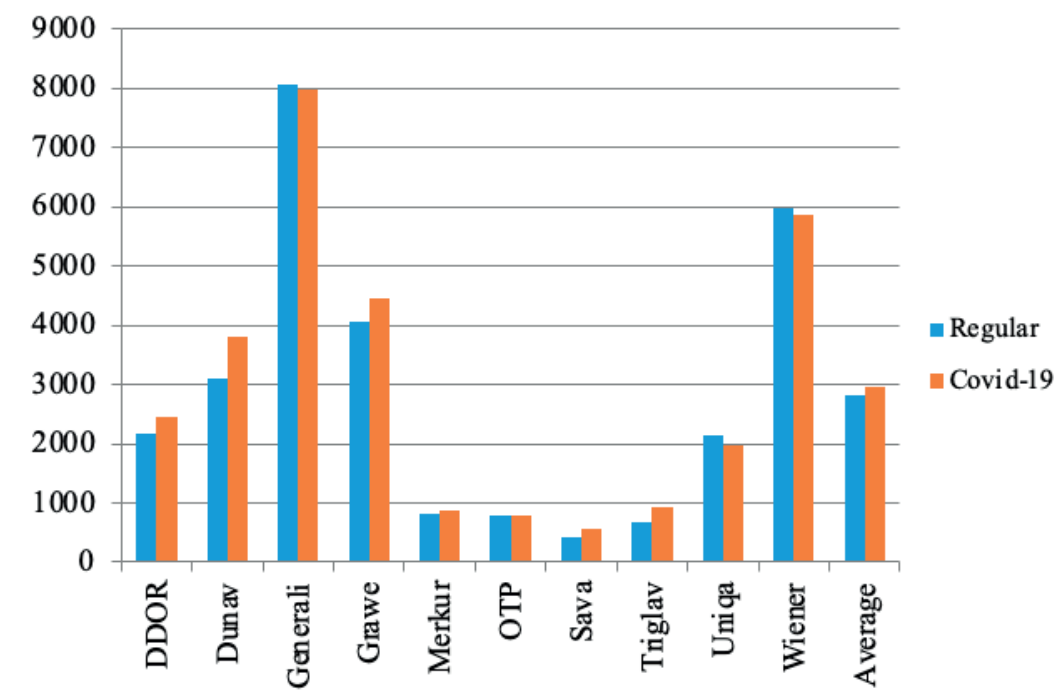


A favourable growth trend in the life insurance premium during the COVID-19 pandemic can be noted when an average value of the premium for this type of insurance is observed. Namely, during the pandemic, the average value of the total life insurance premium has increased from RSD 2,820.06 to 2,965.27 million. Insurance companies in which life insurance premiums have been noted to be above average values in regular conditions and during COVID-19 are Generali Insurance, Wiener Städtische Insurance, Grawe Insurance and Dunav Insurance.

The analysis of data on total and average life insurance premiums in the Republic of Serbia in the period before and during the COVID-19 pandemic has clearly shown that insurance premium payments have increased during the pandemic, which unequivocally confirms the hypothesis that the pandemic has led to an increase in the demand for life insurance, raising people's awareness of the need to protect themselves from the risk of old age and death.

\section{CONCLUSION}

Theoretical consideration in this paper clearly shows that the significance of life insurance is great, multiple, and far-reaching for an individual, economy, and society as a whole. Although the Republic of Serbia significantly lags behind developed countries, in which the culture of saving is at a much more developed, as well as the awareness of the significance of additional savings for old age and protection against risk of death, empirical analysis has shown that life insurance premiums increased during the COVID-19 pandemic in comparison with the period prior to the pandemic. In addition to the total premium in the life insurance sector, the amount of the premium for this type of insurance has increased in most insurance companies. This data clearly shows that the pandemic has positively influenced the demand for life insurance and people's awareness of their lives' priorities, whereby the established hypotheses have been confirmed. Given that insurance companies succeeded in adapting to the new circumstances caused by the COVID-19 pandemic, it can be expected that the trend of increase of the life insurance premium in the Republic of Serbia will continue in the future. Therefore, it is necessary to intensify the started endeavours in educating and informing people about the characteristics and advantages of this type of insurance and the actual state in the pension system of the Republic of Serbia, so that we can understand that life insurance policies are not a luxury, but a realistic human need. A positive effect on the development of human awareness about the need for this type of savings will be on friends and relatives who have already saved up for it. Finally, the possibilities for further development of life insurance in the Republic of Serbia will depend on economic development and the development of the financial market, as well as on employment, earnings and introducing tax exemptions from paying personal income taxes and contributions for mandatory social insurance for employers who pay a life insurance premium on their employees.

\section{REFERENCES}

Čolović, M., \& Mitić, V. (2021). Determinant Factors Influencing Organic Foods Purchase. Acta Agricalturae Serbica, 26(51), 89-95. doi:10.5937/AASer2151089C.

Harris, T. F., Yelowitz, A. , \& Courtemanche, C. J. (2020). Did COVID-19 Change Life Insurance Offerings? Cambridge: National Bureau of Economic Research. Retrieved August 9, 2021, from http://www.nber.org/ papers/w28172.

Kaličanin, K., Brdar, I., \& Vesić, T. (2021). Education is Becoming Digital: The Youth Attitudes Towards Online Teaching During the COVID-19 Pandemic. International Review (1-2), 111-119.

Kočović, J., \& Šulejić, P. (2006). Osiguranje. Beograd: Centar za izdavačku delatnost Ekonomskog fakulteta u Beogradu.

Liedtke, P. (2007). What's Insurance to a Modern Economy? The Geneva Papaers on Risk and Insurance - Issues and Practice (32), 211-221.

Munitlak-Ivanović, O., Mitić, P. \& Raspopović, N. (2014). Stanje i perspektive tržišta životnog osiguranja u Republici Srbiji. Poslovna ekonomija, 8(1), 51-66.

NBS. (2005). Ukupna premija osiguranja po društvima i vrstama osiguranja. Narodna banka Srbije.

NBS. (2006). Ukupna premija osiguranja po društvima i vrstama osiguranja. Narodna banka Srbije.

NBS. (2007). Ukupna premija osiguranja po društvima i vrstama osiguranja. Narodna banka Srbije.

NBS. (2008). Ukupna premija osiguranja po društvima i vrstama osiguranja. Narodna banka Srbije.

NBS. (2009). Ukupna premija osiguranja po društvima i vrstama osiguranja. Narodna banka Srbije.

NBS. (2010). Ukupna premija osiguranja po društvima i vrstama osiguranja. Četvrti kvartal. Narodna banka Srbije.

NBS. (2011). Ukupna premija osiguranja po društvima i vrstama osiguranja. Četvrti kvartal. Narodna banka Srbije.

NBS. (2012). Ukupna premija osiguranja po društvima i vrstama osiguranja. Četvrti kvartal. Narodna banka Srbije.

NBS. (2013). Ukupna premija osiguranja po društvima i vrstama osiguranja. Četvrti kvartal. Narodna banka Srbije.

NBS. (2014). Ukupna premija osiguranja po društvima i vrstama osiguranja. Četvrti kvartal. Narodna banka Srbije.

NBS. (2015). Ukupna premija osiguranja po društvima i vrstama osiguranja. Četvrti kvartal. Narodna banka Srbije.

NBS. (2016). Ukupna premija osiguranja po društvima i vrstama osiguranja. Četvrti kvartal. Narodna banka Srbije. 
NBS. (2017). Ukupna premija osiguranja po društvima i vrstama osiguranja. Četvrti kvartal. Narodna banka Srbije.

NBS. (2018). Ukupna premija osiguranja po društvima i vrstama osiguranja. Četvrti kvartal. Narodna banka Srbije.

NBS. (2019a). Ukupna premija osiguranja po društvima i vrstama osiguranja. Prvi kvartal. Narodna banka Srbije.

NBS. (2019b). Ukupna premija osiguranja po društvima i vrstama osiguranja. Drugi kvartal. Narodna banka Srbije.

NBS. (2019c). Ukupna premija osiguranja po društvima i vrstama osiguranja. Treći kvartal. Narodna banka Srbije.

NBS. (2019d). Ukupna premija osiguranja po društvima i vrstama osiguranja. Četvrti kvartal. Narodna banka Srbije.

NBS. (2020a). Ukupna premija osiguranja po društvima i vrstama osiguranja. Prvi kvartal. Narodna banka Srbije.

NBS. (2020b). Ukupna premija osiguranja po društvima i vrstama osiguranja. Drugi kvartal. Narodna banka Srbije.

NBS. (2020c). Ukupna premija osiguranja po društvima i vrstama osiguranja. Treći kvartal. Narodna banka Srbije.

NBS. (2020d). Ukupna premija osiguranja po društvima i vrstama osiguranja. Četvrti kvartal. Narodna banka Srbije.

NBS. (2021a). Ukupna premija osiguranja po društvima i vrstama osiguranja. Prvi kvartal. Narodna banka Srbije.

NBS. (2021b). Ukupna premija osiguranja po društvima i vrstama osiguranja. Drugi kvartal. Narodna banka Srbije.
Nikolić, M. (2018). Reforma penzijskog sistema Republike Srbije u funkciji njegove održivosti. Doktorska disertacija. Niš: Ekonomski fakultet, Univerzitet u Nišu.

OECD. (2021). Retrieved September 8, 2021, from https:// stats.oecd.org/\#

Olević, S. (2016). Perspektive razvoja životnog osiguranja u Srbiji. Tokovi osiguranja, 32(4), 63-82.

Pjanić, M., Kalaš, B., \& Vasić, N. (2016). Analiza tržišta životnog osiguranja u Srbiji i zemljama u regionu. Anali Ekonomskog fakulteta u Subotici, 52(36), 145-160.

Rakić, B., \& Nikolić, M. (2012). The Role of Public and Private Pension Funds in Creating Financially Sustainable Pension System. In B. Krstić, Improving the Competitiveness of the Public and Private Sector by Networking Competences (pp. 131-145). Niš: Faculty of Economics, University of Niš.

Šulejić, P., Vujović, R., Mrkšić, D., Žarković, N., Rašeta, J., \& Miloradić, J. (2009). Osnovi osiguranja. Beograd: Univerzitet Singidunum.

World Bank Group. (2020). Ekonomski i socijalni uticaj COVID-19. World Bank Group.

Žarković, N. (2008). Ekonomika osiguranja. Beograd: Univerzitet Singidunum. 